\title{
IMPLEMENTASI TERHADAP SUPERVISI PENDIDIKAN DALAM MENINGKATKAN PROSES PEMBELAJARAN DAN KEPROFESIONALAN GURU
}

\author{
OLEH \\ SONIA AFRIANTI (17002104) \\ UNIVERSITAS NEGERI PADANG \\ EMAIL : \\ soniaafrianti04@gmail.com
}

\begin{abstract}
ABSTRAK
Supervisi di suatu sekolah dilakukan oleh kepala sekolah yang berperan sebagai supervisor sekolah. Sebagai supervisor, kepala sekolah harus mampu melakukan berbagai kegiatan baik itu mengawasi serta mengendalikan untuk meningkatkan kinerja guru demi tercapainya pendidikan yang lebih baik. Oleh karena itu kegiatan supervisi yang dilakukan kepala sekolah dari hasil penelitiannya adalah pertama, fokus kegiatan supervisi yang dilakukan kepala sekoalh dapat diidentifikasi kedalam dua hal yaitu : kegiatan yang menyangkut administrasi guru dan kegiatan proses belajar mengajar. Kedua, kegiatan supervisi sangat membantu bagi guru dalam memecahkan masalah pendidikan yang dihadapi guru pada saat melakukan pembelajaran, serta dapat memberikan motivasi bagi guru agar selalu meningkatkan pengetahuan untuk menjadi guru yang profesional dalam melaksanakan pembelajaran. Ketiga, hambatan kepala sekolah dalam supervisi adalah tumpang tindih kegiatan dan keterbatasan dana operasional.
\end{abstract}

Kata Kunci : Supervisi, Kepala Sekolah, Profesional, Pembelajaran.

\section{A. PENDAHULUAN}

\section{Latar Belakang Masalah}


Supervisi merupakan kegiatan yang dilakukan oleh seorang supervisor untuk melakukan berbagai kegiatan pengawasan dan pengendalian terhadap kinerja guruguru demi meningkatkan mutu pendidikan. Guru memliki potensi untuk berkreasi dan meningkatkan kinerjanya demi tercapainya peningkatan mutu pendidikan. Namun, karena banyaknya faktor yang menghambat masalah yang dihadapi guru-guru dalam mengembangkan berbagai potensinya secara optimal, baik itu dari kemampuan guru dalam proses belajar mengajar, maupun dalam sarana dan prasarana pendidikan yang tersedia. Oleh karena itu, sangat diperlukan adanya supervisi yang berkelanjutan atau berkesinambungan dengan adanya program yang terarah dan sistematis terhadap guru. Program supervsisi tersebut disebut dengan suatu rangkaian yang penting dalam manajemen pendidikan.

Didalam Al-Qur'an Surat Al-'Ashr ayat 3 pun dijelaskan hal yang menyangkut tentang supervisi dalam artian luas yaitu dalam hal saling nasehat menasehati dalam kebenaran dan saling nasehat - menasehati dalam kesabaran. Jadi, bahwa pesan tersebut saling menasehati dalam kebaikan dan kesabaran merupakan kunci dalam menyelenggarakan supervisi pendidikan di sekolah dalam hal peningkatan mutu pendidikan, perbaiakan akhlak, dan tata cara beretika serta dalam pemberian motivasi guna pencapaian mutu pendidikan di sekolah. Maka kepala sekolah yang bertindak sebagai supervisor harus mampu melakukan berbagai kegiatan pengawasan dan pengendalian untuk meningkatkan mutu kinerja guru.

\section{Rumusan Masalah}

Permasalahan yang ada dalam jurnal ini adalah kita harsu memahami terlbeih dahulu apa yang dimasud dengan supervisi pendidikan itu sendiri, serta tujuan dan fungsi supervisi pendidikan itu, dan belum terlaksananya supervisi pendidikan oleh kepala sekolah yang memberikan kontribusi positif terhadap peningkatan kinerja guru dalam proses belajar mengajar seperti adanya sebagian guru yang mengajar lepas, dalam arti tidak menggunakan acuan yang telah ditetapkan untuk di emban guru, contohnya guru mengajar tidak menggunakan Silabus, Kurikulum, Program Tahunan, Program Semester, dan Rancangan Program Pembelajaran (RPP), serta kurangnya disiplin dan tanggung jawab terhadap tugas yang sedang dilakukan.

\section{Tujuan Penulisan}


Dari rumusan masalah tersebut, tujuan penulisan jurnal tersebut ialah kepala sekolah sebagai supervisor pendidikan agar mampu melakukan berbagai kegiatan pengawasan dan pengendalian terhadap kinerja-kinerja guru dalam proses belajar mengajar demi meningkatkan mutu pendidikan.

\section{B. PEMBAHASAN}

\section{Ringkasan Artikel}

\section{a. Pengertian Supervisi Pendidikan}

Kata supervisi berasal dari Bahasa Inggris yaitu Supervision, terdiri dari kata yaitu super dan vision yang mengandung pengertian melihat dengan sangat teliti terhadap pekerjaan secara keseluruhan. Orang yang melakukan supervisi disebut dengan supervisor. Menurut Suharsimi menjelaskan, bahwa supervisi terdiri dari dua kata "super" dan "vision" yang berarti "melihat" maka secara keseleruhan supervisi diartikan sebagai melihat dari atas. Dengan demikian supervisi dapat dikatakan sebagai kegiatan yang dilakukan oleh kepala sekolah yang berkedudukan diatas lebih tinggi dari guru untuk melihat dengan teliti pekerjaan secara keseluruhan atau mengawasi pekerjaan guru. Menurut Ali Imran, supervisi pendidikan adalah serangkaian bantuan kepada guru, terutama bantuan yang berwujud layanan profesional untuk meningkatkan proses belajar mengajar. Dan menurut Sahertian, supervisi pendidikan adalah sebagai pemberian layanan dan bantuan guna meningkatkan kualitas pendidikan.

Ada tiga unsur penting yang harus diperhatikan dalam supervisi pendidikan yaitu :

1) Unsur proses pengarahan, bantuan atau pertolongan dari pihak atasan atau pihak yang lebih memahami.

2) Unsur guru-guru dan personalia sekolah lainnya yang berhubungan langsung dengan belajar mengajar para siswa sebagai pihak yang diberikan pertolongan.

3) Unsur proses belajar mengajar atau situasi belajar mengajar sebagai objek yang diperbaiki.

\section{b. Tujuan dan Fungsi Supervisi Pendidikan}

Tujuan supervisi menurut Hariwung adalah sebagai pengendalian kualitas, pengembangan profesional dan untuk memotivasi guru. Supervisi 
sebagai pengendalian kualitas artinya, kepala sekolah sebagai supervisor bertanggung jawab memonitor proses belajar mengajar disekolah dengan cara berkunjung ke kelas, berkonsultasi dengan guruyang dapat diharapkan pendidikan mampu menilai dan mengetahui kemampuan siswa.

Adapun fungsi utama supervisi pendidikan ditujukan pada perbaikan dan peningkatan proses belajar mengajar guru disekolah. Sehubungan dengan hal ini menurut pendapat Malik, supervisi terhadap kinerja guru dalam proses belajar mengajar ada tiga fungsi yaitu :

a) Supervisi kurikulum untuk menjamin penyampaian kurikulum dengan tepat.

b) Perbaikan proses pembelajaran dengan membantu guru merencakanan proses akademis.

c) Pengembangan profesi dalam melaksanakan program pengajaran.

\section{c. Kepala Sekolah Sebagai Supervisor}

Pelaksanaan supervisi pendidikan oleh kepala sekolah harus mampu melakukan berbagai pengawasan dan pengendalian untuk meningkatkan proses belajar mengajar. Soetjipto dan Raflis Kosasi dalam bukunya Profesi keguruan mengatakan bahwa tugas supervisor meliputi:

1) Tugas perencanaan, yaitu untuk menetapkan kebijaksanaan dan program

2) Tugas administrasi, yaitu pengambilan keputusan serta pengkoordinasian melalui konferensi dan konsultasi yang dilakukan dalam usaha perbaikan kualitas pengajaran.

3) Partisipasi secara langsung dalam pengembangan kurikulum, yaitu dalam kegiatan merumuskan tujuan, membuat penuntun mengajar bagi guru, dan memilih isi pengalaman belajar.

4) Melaksanakan demonstrasi mengajar untuk guru-guru.

5) Melaksanakan penelitian.

Dalam melaksanakan tugasnya, supervisi membantu memberi support mengajak mengikutsertakan guru dalam memperbaiki proses belajar mengajar. Seorang supervisor dapat berperan sebagai koordinator, konsultan, pemimpin kelompok dan evaluator.

\section{d. Hasil Penelitian Penyusunan Program Supervisi Pendidikan}


Dari penelitian yang telah dilakukan Cut Suryani dapat ungkapkan penyusunan program supervisi pendidikan dilaksanakan oleh kepala sekolah melibatkan wakil kepala sekolah dan guru-guru. Hal ini telah dibuktikan dalam wawancaranya dengan Wakil kepala Sekolah MIN Sukadamai Kota Banda Aceh, yang mengatakan kepala sekolah mengajak mereka, guru-guru senior dalam penyusunan program supervisi pendidikan. Kepala sekolah mengatakan penyusunan program supervisi pendidikan dibuat pada awal tahun ajaran. Hal ini dimaksudkan supaya program kegiatan dapat diintegrasikan dalam kegiatan sekolah secara komprehensif. Dan penyusunan program supervisi pendidikan dilaksanakan pada awal semester ganjil atau pada awal tahun ajaran. Demikian juga pelaksanaannya, evaluasi program supervisi pendidikan dilakukan pada setiap akhir semester ganjil dan semester genap dengan tujuan dapat mengetahui sejauhmana pencapaian program supervisi yang telah dilaksanakan.

Upaya yang dilakukan oleh kepala sekolah dalam pelaksanaan supervisi pendidikan meliputi penyusunan program tahunan, program semester, dan persiapan lainnya yang harus dipersiapkan oleh seorang guru, dan mengadakan kunjungan supervisi ke kelas, serta penyusunan laporan tindak lanjut hasil supervisi. Kepala sekolah melakukan supervisi terhadap komponen pendidikan sekolah. Pelaksanaan supervisi pendidikan yang dilakukan oleh kepala sekolah lenih menekankan pada pembinaan terhadap kemampuan guru dalam mengelola pembelajaran, mengenai cara pelaksanaan supervisi pendidikan yang dilakukan kepala sekolah terhadap guru-guru.

\section{e. Supervisi Pendidikan dan Pengembangan Sumber Daya Guru}

Upaya kepala sekolah dalam pengembangan sumber daya guru diantaranya adalah

1) Upaya pembinaan kemampuan guru dalam penguasaan materi ajar

Dalam upaya yang dilakukan kepala sekolah dalam pengembangan sumber daya guru guna meningkatkan penguasaan materi ajar, antara lain: guru mengikuti kegiatan Musyawarah Guru Mata Pelajaran (MGMP), mengikuti Kelompok Kegiatan Guru (KKG), mengirim guru untuk mengikuti pelatihan dan penataran yang berhubungan dengan pengembangan profesionalisme guru. 
2) Upaya pembinaan kemampuan dalam menggunakan penguasaan metode pembelajaran

Metode mengajar disesuaikan dengan situasi dan kebutuhan siswa. Penggunaan metode belajar yang tepat dan bervariasi menyebabkan siswa merasa antusias mengikuti pelajaran, sehingga ada siswa yang menyukai guru tertentu dan tidak menyukai guru yang lain. Dengan upaya pembinaan kemampuan guru dalam menggunakan metode pembelajaran yang efektif dan efisien, antara lain: peningkatan bekal pengetahuan kepada guru, pengiriman guru dalam kegiatan ilmiah sperti pelatihan, penataran, dan diskusi sesama guru untuk meningkatkan kompetensi guru dalam menyelesaikan masalah pembelajaran yang dihadapi dalam menjalankan tugasnya.

3) Upaya pembinaan kemampuan dalam teknik evaluasi pembelajaran

Dapat diketahui bahwa melalui supervisor guru juga dibantu untuk memahami fungsi-fungsi evaluasi, yaitu fungsi formatif, fungsi sumatif, dan fungsi diagnostik. Dari ketiga fungsi evaluasi tersebut, yang paling banya melibatkan supervisor adalah fungsi diagnostik, yaitu evaluasi untuk mengungkapkan kesulitan belajar sehingga dapat di diagnosis untuk program remedial. Dalam bantuan supervisor di dalam mendiagnosis kesulitan belajar siswa dapat membantu guru untuk menentukan langkahlangkah kreatif bagi peningkatan hasil belajar.

\section{f. Signifikansi Supervisi Pendidikan dalam Meningkatkan Proses Belajar Mengajar}

Kegiatan supervisi pendidikan yang dilakukan oleh kepala sekolah terhadap guru dalam meningkatkan kualitas hasil belajar mengajar secara formal dilakukan dengan terjadwal. Untuk supervisi terhadap administrasi guru dilakukan setiap awal tahun atau menjelang semester, sedangkan untuk kegiatan belajar mengajar, kegiatan supervisi dilakukan pada hari - hari dilaksanakannya kegiatan belajar mengajar. Pelaksanaan supervisi pendidikan yang dilakukan oleh Kepala Sekolah dirasakan sangat penting dan bermanfaat bagi guru khususnya membantu meningkatkan kemampuan guru dalam mengelola kegiatan belajar mengajar. Upaya yang dilakukan guru terhadap kendala-kendala yang dihadapi dalam membuat perencanaan kegiatan belajar mengajar antara lain: untuk mengatasi masalah keterbatasan waktu membuat 
perencanaan kegiatan belajar mengajar, maka perencanaan dilakukan dengan mengoptimalkan waktu luang yang dimiliki guru atau dilakukan dengan jalan membuat perencanaan program belajar mengajar bersama-sama.

Berkaitan dengan penggunaan metode yang digunakan guru dalam melakukan proses belajar mengajar menurut seluruh responden tidak terpaku pada satu metode saja, melainkan melakukan berbagai metode agar tercapai tujuan yang diharapkan dari materi yang diberikan. Dan hal yang berkaitan dengan pelaksanaan evaluasi dalam rangka menilai keberhasilan guru terhadap penilaian yang dilakukan pada proses KBM dengan cara lisan melalui pertanyaan-pertanyaan, tulisan maupun hasil pengamatan terhadapa siswa, dan tes formatif. Maka tindakan guru selanjutnya adalah memberikan remedial kepada siswa tersebut agar yang belum memenuhi standar tersebut mengerti dan paham terhadap materi yang disampaika oleh guru tersebut.

\section{Kajian Analitis}

Supervisi pendidikan disekolah dilakukan oleh kepala sekolah untuk melakukan pembinaan kepada kinerja-kinerja guru. Kepala sekolah adalah seorang sipervisor yang harus mampu melakukan berbagai kegiatan pengendalian dan pengawasan kepada kinerja guru-guru yang masih belum mampu melakukan tugasnya dengan baik, maka dari itulah kepala sekolah melakukan pengawasan dan pengendalian kepada guru-guru agar menjalankan tugasnya melalui pemberian bimbingan atau penataran kepada guru-guru tersebut. Supervisi pendidikan disekolah sangat memiliki peran penting dalam meningkatkan kualitas pembelajaran guru yang menghasilkan prestasi belajar siswa yang baik. Didalam jurnal Ahmad Sabandi yang berjudul "supervisi pendidikan untuk pengembangan profesionalitas guru berkelanjutan" mengatakan bahwa " supervisi pendidikan berkembang seiring dengan ilmu manajemen. Pada awalnya perkembangannya, supervisi dilakukan dengan pendekatan inspeksi. Supervisor datang ke sekolah dan mengamati guru mengajar. Fokus perhatian supervisor adalah menemukan kesalahan guru berdasarkan standar kerja baku yang dirumuskan sedemikian rupa oleh otoritas pendidikan. Guru melaksanakan tugas sesuai dengan prosedur operasional yang standar. Supervisor dengan guru merupakan dua pihak sebagai atasan dan bawahan. Supervisor memiliki tingkat kebenaran yang lebih tinggi dari pada guru. " Jadi, disini maksudnya supervisor atau kepala sekolah ini lebih berperan penting dan kekuasannya lebih tinggi dari guru sebagai bawahannya, 
maka guru harus menuruti perintah atasannya yaitu memberikan pelayanan pendidikan yang lebih baik dan mampu membimbing peserta didiknya agar berprestasi dan berakhlak mulia.

\section{PENUTUP}

\section{Kesimpulan}

Pelaksanaan supervisi pendidikan dilakukan Kepala Sekolah didahului dengan penyusunan program supervisi yang dipersiapkan pada awal tahun ajaran. Selanjutnya dengan pelaksanaan yang dilakukan setiap awal semester dan akhir semester pada saat berlangsungnya kegiatan proses belajar mengajar untuk melihat keberhasilan sejauh mana program yang telah dipersiapkan dapat terealisasi. Fokus kegiatan supervisi yang dilakukan kepala sekolah diidentifikasi dalam dua hal yaitu: pertama kegiatan supervisi yang menyangkut semua persiapan yang harus disiapkan oleh guru sebelum melakukan pembelajaran. Kedua, kegiatan supervisi yang menyangkut dengan kegiatan proses belajar mengajar.

Pelaksanaan supervisi pendidikan dilakukan oleh kepala sekolah meliputi penyusunan program tahunan, kunjungan supervisi ke kelas, dan penyusunan laporan tindak lanjut hasil penelitian. Program tahunan disusun dengan tujuan meningkatkan kualitas pendidikan melalui penilaian dan pembinaan terhadap teknis dan administrasi pendidikan di sekolah, dan memberikan pedoman serta kejelasan bagi guru dalam rangka penyusunan program semester/tahunan dan dijabarkan berdasarkan hasil rapat guru tahun sebelumnya. Pelaksanaan supervisi pendidikan yang dilakukan kepala sekolah lebih menekankan pada pembinaan terhadap kemampuan guru dalam mengelola pembelajaran.

Kaitan supervisi pendidikan dengan kepala sekolah terhadap proses belajar mengajar adalah sangat membantu bagi guru dalam memecahkan masalahmasalah pendidikan yang diahadapi guru serta dapat memberikan motivasi bagi guru agar selalu meningkatkan pengetahuan untuk menjadi guru yang profesional dalam melaksanakan pembelajaran. Hambatan yang dialami kepala sekolah adalah sering timbulnya tumpang tindih terhadap kegiatan yang dilakukan bersamaan, sehingga program yang telah disiapkan kadang harus ditunda, karena adanya kegiatan yang mendesak seperti rapat dinas yang harus didahului.

\section{Saran}


Upaya yang dapat dilakukan adalah mencari jadwal yang tepat untuk pelaksanaan supervisi pendidikan yang dimaksud. Keterbatasan dana operasional sekolah untuk pembinaan guru, sehingga perlu upaya untuk melaksanakan pembinaan guru yang biasanya dilakukan dua kali dalam setahun, mengingat keterbatasan dana, maka dilaksanakan satu kali dalam setahun saja.

Diharapkan kepada supervisor atau kepala sekolah agar dapat membantu para guru untuk meningkatkan kinerjanya demi mencapai tujuan pendidikan yaitu meningkatkan mutu pendidikan. Dan diharapkn juga kepada guru-guru agar mampu mengajar para peserta didiknya dengan baik sesuai silabus, kurikulum, program tahunan,semester yang ada.

\section{REFERENSI}

Arikunto, Suharsimi. 2004. Dasar-Dasar Supervisi. Jakarta : PT Rineka Cipta

Hariwung. 1989. Supervisi Pendidikan. Jakarta : Depdikbud

Imron, Ali. 1995. Pembinaan Guru di Indonesia. Jakarta : Dunia Pustaka Jaya

Malik. 2000. Pedoman Manajemen Madrasah. Yogyakarta : Forum Kajian Agama Dan Budaya

Sahertian. 2000. Konsep Dasar Dan Teknik Supervisi Pendidikan Dalam Rangka Pengembangan Sumber Daya Manusia. Jakarta : PT Rineka Cipta

Sabandi, A. (2013). Supervisi Pendidikan Untuk Pengembangan Profesionalitas Guru Berkelanjutan. PEDAGOGI, Jurnal Ilmiah Ilmu Pendidikan, VIII(2), 1-9.

Suryani, C. (2015). Implementasi Supervisi Pendidikan Dalam Meningkatkan Proses Pembelajaran Di Min Sukadamai Kota Banda Aceh. Jurnal Ilmiah DIDAKTIKA, 16(1), 23-42. 